\title{
Commentary
}

\section{Hearing the Unheard: Voices of the Silent}

\author{
Patitapaban Das*
}

\begin{abstract}
With regards to ecology, there has been a constant struggle between the scientific perspective and the philosophical approaches. This commentary dwells on the nature and structure of voices emerging from feminist environmentalists. Analogous to the feminist understanding that environmental degradation is a symbol of masculine domination leading to the suppression of the feminine, this paper tries to excavate the nature of a feminist perspective to environmental ethics.
\end{abstract}

Keywords: Modernity, Dominance, Anthropocentrism, Biocentrism, Ecofeminism

\section{Introduction}

Scientists, policymakers, environmental activists and philosophers around the globe are working ceaselessly to curtail the problem of environmental catastrophes. Since the scientific solutions seem fuzzy, philosophers are in search of alternative predicaments to challenge the traditional view regarding the environment. In this regard, the traditional predicament fitted with modernity has to be rejected. To do that, one needs to question the basic conceptual scaffoldings of mighty modernity. The feminist approach to environmental problems has adequate strength to do this job.

\footnotetext{
* Department of Philosophy, Ravenshaw University, Cuttack, Odisha, India; pdas@ravenshawuniversity.ac.in
} 
At the outset, the authenticity and morality of basic concepts of modernity will be questioned and how these concepts are responsible for making a dividing and dominating predicament towards nature much similar towards the feminine by the masculine will be shown. Further, the feminist view as an alluring alternative to solve the environmental problems by dissolving the seeming bifurcation will be provided. The study is limited to the feminist approach that contributes to the development of environmental philosophy.

\section{Modernity and Discontent}

A seeming truism is to assert that the source of ongoing natural catastrophes and environmental crisis is the anthropocentric paradigm'. The paradigm, dating back to Greek philosopher Protagoras via Aristotle, and Christianity and manifested through modern science, constructed a man-centred universe. That this paradigm has destroyed nature enormously can be conspicuously verified in the morning news. While few are scary like those that read that the mighty ocean would eat up megacities like Kolkata, Chennai and Mumbai, others are incredulous like those that forecast that the earth would end up drying like Mars. All these news items may be mixed up with some facts and fantasies, but undoubtedly, they have sufficiently shaken up our apprehensions towards nature. That's why the age-old anthropocentric predicament is being suspected as a bane in the pretence of a boon.

Anthropocentric paradigm is only the tip of the ice-berg. In recent years, much of the philosophical canon has come under critical scrutiny both from the eastern and western theorists. Critical theory, deep ecology, and feminism have all called for a reassessment of the Western philosophical heritage (Moyer, 2001). There is a consensus among writers that the western philosophical tradition that endorses modernity divides the world thereby fostering domination. Delineating the essential feature of this world view, Ashis Nandy, an Indian critical theorist opines:

Many many decades later, in the aftermath of that marvel of modern technology called the Second World War and perhaps 
that modern encounter of cultures called Vietnam, it has become obvious that the drive for mastery over men is not merely a by-product of a faulty political economy but also of a world view which believes in the absolute superiority of the human over the nonhuman and the subhuman, the masculine over the feminine, the adult over the child, the historical over the a-historical, and the modern or progressive over the traditional or the savage. (Nandy, 2009)

This world view is very often referred to as 'the west' by third world countries. It encompasses the whole globe by its most precarious weapon called colonialism through modernity, science and technology. No wonder Nandy claims that the West is now everywhere, within the West and outside; in structures and minds (Nandy, 2009). It is assumed that most of the suppression and domination around the world are caused due to this world view widely represented by the west. Nandy again explains:

It has become more and more apparent that genocides, eco disasters and ethnocides are but the underside of corrupt sciences and psychopathic technologies wedded to new secular hierarchies, which have reduced major civilizations to the status of a set of empty rituals. The ancient forces of human greed and violence, one recognizes, have merely found a new legitimacy in anthropocentric doctrines of secular salvation, in the ideologies of progress, normality and hyper-masculinity, and in theories of cumulative growth of science and technology. (Nandy, 2009)

\section{The Ecofeminist Agenda}

Ecofeminists, though do not represent a monolithic philosophical strand also perceive the modernity in the same shade. Their concern, however, is more on the exploitation of nature, the structure and nature of such exploitation, and possible solutions for it. The idea that the rise of modern science, technology, and capitalism produced and relied on the death, domination, and exploitation of nature gendered female, and that this reinforced and reflected the cultural subordination and exploitation of women, is the kind of large and provocative thesis of which academia has too few (Thompson, 2006). 
The term ecofeminism was advanced by Francoise d'Eanbonne in 1974 to capture women's potential for bringing about an ecological revolution to ensure the survival of the planet. Greta Gaard aptly defines, "Ecofeminism is a theory that has evolved from various fields of feminist inquiry and activism: peace movements, labour movements, women's health care, and the anti-nuclear, environmental, and animal liberation movements. Drawing on the insights of ecology, feminism, and socialism, ecofeminism's basic premise is that the ideology which authorises oppressions such as those based on race, class, gender, sexuality, physical abilities, and species is the same ideology which sanctions the oppression of nature. Ecofeminism calls for an end to all oppressions, arguing that no attempt to liberate women (or any other oppressed group) will be successful without an equal attempt to liberate nature. Its theoretical base is a sense of self most commonly expressed by women and various other nondominant groups - a self that is interconnected with all life!" (Gaard, 1993).

Ecofeminists are not however in consensus on how to achieve such a goal. There are divergent strands that run parallel within the ecofeminists' debate.

1. Women's participation in resolving the environmental crisis is preliminary since women are closer to nature in a special way. This is known as the essentialist view in ecofeminism.

2. The source of exploitation of nature and that of women is historically the same patriarchal thought which rests on dualistic metaphysics. So to resolve the environmental crisis, we have to crash this conceptual cleavage. This is known as the conceptualist view in ecofeminism.

3. A mode of thought rested on the vocabulary of care is essential in both cases to comprehend the environmental crisis.

This paper focusses on articulating the structure of vocabulary used in ethics of care employed both by the essentialists and the conceptualists even though the essentialists' view is critiqued by the ecofeminist writers. The author argues that the idea of an embedded self, endorsed by the ecofeminists and also subscribed by many 
dominated groups will provide the much-needed strength for the vocabulary of ethics founded on the concept of care.

The essentialists claim that women have a special connection with nature. Thompson puts it, "ecofeminists follow an essentialist strategy and argue that women are closer to nature. By their closer relationship to nature, it is claimed that women are more likely than men to care about nature and are better prepared to do so than men. The vocabulary of an ethics of care is seen from this perspective to emerge as the essential voice of women's lived experience and sense of self as embedded in relationship" (King Roger, 1991). Many ecofeminists celebrated women's putative life-giving and holistic reproductive and spiritual capacities and tied these gendered qualities to an ability to care for and protect the earth from rapacious natural resource extraction, militarism, and ecological disharmony (Thompson, 2006). Women, as Salleh puts it, "flow with the system of nature" (Salleh, 1984). According to Salleh, "Woman's monthly fertility cycle, the tiring symbiosis of pregnancy, the wrench of childbirth and the pleasure of suckling an infant, these things already ground a woman's consciousness in the knowledge of being coterminous with Nature" (Salleh, 1984).

However, more and more feminist thinkers are detaching themselves from this essentialist view. More and more urbanised women are as detached as the men from the wilderness in the contemporary world. So the claim that women are more connected with nature, is losing empirical grounds. King contends, "In the increasingly urban societies of Western Europe and North America, it might be argued that the relation to nature is no more "given" for women than it is for men. Both women and men are increasingly cut off from direct experiential relationships with nature, as opposed to artificial and urban, environments, and thus, although we are unavoidably related to the non-human world, we do not (many of us) experience that relationship with nature as "given" in all its concreteness and complexity (King Roger, 1991). Similarly, many thinkers are also alleging that the essentialist view is in reality anthropocentrism in disguise. To paraphrase such predicament of allegation Roger J. H. King opines: 
But this quotation underscores the necessity of examining what exactly it is that ecofeminists care about when they care about nature and how this care is determined by why they feel a connection with "lived experience"? The connection with nature that Salleh draws upon is the connection to a woman's bodily nature or, more precisely, only to her reproductive nature. Awareness of this connection and the care for it that can emerge have a logic that can link a woman's relation to her reproductive nature to a relation to the environment more generally. Articulating this logic, many ecofeminists have focused on those aspects of environmental destruction that impinge directly or indirectly on women's reproductive nature, that is, on the consequences of the environmental crisis for individual and local community health and the conditions necessary for nurturing the life and growth of future generations of human beings. (King Roger, 1991)

\section{The Conceptual Agenda}

In contrast, some ecofeminists follow a conceptualist strategy. They claim that an ecofeminist environmental ethics must redress the conceptual opposition that patriarchal culture sets up between men and culture on the one hand and women and nature on the other. These dualisms underlie a parallel that exists between the oppression of women and the domination of nature in a patriarchal society. Although a conceptualist environmental ethics does not claim that the vocabulary of care represents the essential moral voice of women, this vocabulary does offer conceptual resources that have been ignored by much of contemporary environmental ethics (Warren, 1990).

This conceptualist predicament attracted a plethora of feminist writers. Carolina Merchant brought out her magnificent book entitled the Death of Nature: Women, Ecology, and the Scientific Revolution during the 80s which has been regarded as the groundwork in ecofeminist philosophy. Robin May Schott (1993), Mary Meller (1997), Karen J. Warren (1998), and Val Plumwood (1993) have enriched conceptualist literature. Each of these celebrated writers sees a conceptual cleavage 
endorsed by the patriarchal thought much common in the philosophy of modernity responsible for the ongoing plight of nature. The modern philosophy endorses a metaphysical and normative dualism which for Plumwood is different from mere binary or dichotomy. This dualism contrasted nature from culture, men from women, and mind from body. Furthermore, it simply did not separate them but subordinated one by the other. It created a value hierarchy. This predicament, however, gave rise to the vocabulary of right versus responsibility, triggered the voice of power translated into the language of subordination and domination or inferior and superior.

In her seminal work Feminism and the Mastery of Nature (1993), Plumwood enlists the features of such dualist metaphysics. Dualism creates two realms known as "backgrounding" and "foregrounding". Things in the "foreground" push the other into the "background" to remain in the "foreground". The master (experiencing subject) exists in the foreground and makes use of the background. Dualism then excludes the background forever from the discussion which Plumwood names radical exclusion or hyperseparation. The next step follows to objectify the 'other', using the other as a mere object. This is known as instrumentalism or objectification. The "underdog" of the pair is conceptualised as a mere means to the "overdog's" goal or end. The next step of exclusion culminates in homogenisation or stereotyping where the dominated group is stereotyped or bracketed forever. Plumwood therefore, concludes that to smash the exploitation of women or nature, this dualism that triggers domination has to be crashed for completely. The central goal of ecofeminism is identifying and overcoming normative dualisms and that (such) dualism in the received view of nature concludes that nature is inferior to culture (Wilson, 1997).

The centre of such a dualistic predicament is its overemphasis on an idea of self which is detached, disengaged and abstract. The idea of such a detached self expresses itself in languages of right, justice, impartiality and universality. The nature perceived by this module as the self's 'other', destruction of it or 'using' it for self's cause is considered morally laudable. The opposite voice, which was almost 
silenced within this predicament, depicts a self which is engaged, embedded and embodied. The self that is connected with the other strongly cares for it. It does not believe in the power hierarchy. Marti Kheel claims that much of the discussion of environmental ethics has failed to make "the open admission that we cannot even begin to talk about the issue of ethics unless we admit that we care (or feel something). And it is here that the emphasis of many feminists on personal experience and emotion has much to offer in the way of reformulating our traditional notion of ethics" (Kheel, 1985).

Ecofeminists begin their theory by critiquing theories like moral existentialism and deep ecology. Peter Singer and Tom Regan are considered to be moral existentialists. They extend moral claims for other human beings based on certain abstract and universal traits, which the ecofeminists claim to be too abstract to capture. Peter Singer for instance bases his theory on the principle of a feeling of pain and pleasure on which he extends moral worth of nonhuman beings. Similarly, Tom Regan refers to the capacity of being conscious as the criterion of moral extension. As a result, we learn to perceive the individual, whether human or nonhuman, primarily in the light of the traits that have been abstracted. However, as Margaret Urban Walker notes, that reliance on general criteria of moral worth, " presses me to view you, for instance, as a holder of a certain right, or a promisee ... or a focus of some specifiable set of obligatory responses. I am pressed to structure my response or appeal to you in terms which I can think of as applying repeatedly to any number of other cases" (Walker, 1989).

For ecofeminists, too much emphasis on generality and abstract principles undermine the connectedness of human self and its concrete relationship. Such abstract and general principles and their vocabulary of rights, duties, and obligations obscure "the importance of attending to the needs of those with whom we are in relation" (Lauritzen, 1989). Ecofeminists depict human relationship and its givenness in nature as a web. As such, human existence is necessarily interconnected and moral excellence is about maintaining the balance among all these divergent determiners of the web. This image "symbolizes the interdependence that is thought to characterize human relations, according to feminist thought. We 
are, each of us, at every point in our lives, inextricably tied to others. We are always someone's daughter or sister, mother, son, brother or father; we are always members of a community" (Lauritzen, 1989). For ecofeminists, this community extends beyond the human species to our relations with other animals, trees and plants, places and ecosystems (Zimmerman, 1987).

The vocabulary of such a mode of thought will be fundamentally different from that of right and justice as depicted in the mode of thought which banks on the idea of a detached and disengaged self. One can see that this language forms a different voice. To summarise the essential feature of such voice Carol Gilligan writes:

In this conception, the moral problem arises from conflicting responsibilities rather than from competing rights, and requires for its resolution a mode of thinking that is contextual and narrative rather than formal and abstract. This conception of morality as concerned with the activity of care centers moral development around the understanding of responsibility and relationships, just as the conception of morality as fairness ties moral development to the understanding of rights and rules. (Gilligan, 2003)

Similarly, Karen Warren opines:

Ecofeminism is a contextualist ethic. It involves a shift from a conception of ethics as primarily a matter of rights, rules, or principles pre-determined and applied in specific cases to entities viewed as competitors in the context of moral standing, to a conception of ethics as growing out of what Jim Cheney calls "defining relationships," i.e., relationships conceived in some sense as defining who one is... Ecofeminism makes a central place for values of care, love, friendship, trust, and appropriate reciprocity - values that presuppose that our relationships to others are central to our understanding of who we are (Warren, 1990).

The language of such a voice stands on feelings, emotional bindings with others. This voice, however, has been silenced by the idea of private and public dichotomy. The private is good at maintaining a relationship within the boundary of family. However, this is 
inadequate in the public sphere where a relationship is defined by top-notch competition and tough bargaining. Contemporary political theorists see this public-private dichotomy as a constructed and structured myth. For Marx, justice is not required and will not be claimed in a perfect society where people respond to others' needs spontaneously. The communitarians, the multiculturalists by their respective planes push this idea further. The nucleolus of such predicament, however, has to bank upon an idea of self that is connected, passionate, engaged, embedded and embodied. The connected self is contextual, captures the concrete individual with all its givenness.

\section{Conclusion}

The metaphysical stance referred to at the beginning of this paper depicted an empty self which is free to question its participation in existing social practices, and opt-out of them, should those practices seem no longer worth pursuing. This is the worst kind of liberal view that made humanity utterly self-centric, individualistic and selfish. Rawls summarises this liberal view by saying that 'the self is prior to the ends which are affirmed by it' (Rawls, 1971) by which he means that we can always step back from any particular project and question whether we want to continue pursuing it. This is known as Kantian view of the self since Kant vehemently views that the self is before its socially given roles and relationships, and is free only if it is capable of holding these features of its social situation at a distance and judging them according to the dictates of reason (Tayler, 1979).

The utilitarian's 'U-agent' or Kant's rational man, therefore, became too mechanical in the hand of the reason that it lost its rationality. For feminists, communitarians or other subaltern groups, this is a false view of the self. It ignores the fact that the self is 'embedded' or 'situated' in existing social practices, that we cannot always stand back and opt-out of them. This self engages itself with the commitments and the given. Kymlicka opines, 'our social roles and relationships, or at least some of them, must be taken as given for personal deliberation' (Kymlicka, 2002). As MacIntyre puts it, 'in deciding how to lead our lives, we all approach our own circumstances as bearers of a particular social identity...Hence, what 
is good for me has to be the good for one who inhabits these roles' (MacIntyre, 1981). Therefore, an embedded self is preliminary to listen to the voices emerged from the wilderness which was otherwise subjected to be dominated, domesticated and finally destroyed.

\section{References}

Gaard, G. (1993). Living Interconnections with animals and naturee. In G. Gaard, \& G. Gaard (Ed.), Ecofeminism: women, animals, nature. Philadelphia: Temple University Press.

Gilligan, C. (2003). In a different voice: psychological theory and women's development. Cambridge: Harvard University Press.

Kheel, M. (1985). The liberation of nature: A circular affair. Environmental Ethics, 6, 344.

King Roger, J. H. (1991). Caring about nature: feminist ethics and the environment. Hypatia, 6(1), 76.

Kymlicka, W. (2002). Contemporary political philosophy: An introduction. Oxford: Oxford University Press.

Lauritzen, P. (1989). A feminist ethic and the new romanticism-mothering as a model of moral relations. Hypatia, 4(2), 32.

MacIntyre, A. (1981). After virtue: A study in moral philosophy. London: Duckworth.

Moyer, J. (2001). Why Kant and Ecofeminism don't mix. Hypatia, 79-97.

Nandy, A. (2009). The intimate enemy: loss and recovery of self under colonialism. Delhi: Oxford University Press.

Rawls, J. (1971). A theory of justice. London: Oxford University Press.

Salleh, A. K. (1984). Deeper than deep ecology: The Eco-feminist connection. Environmental Ethics, 6, 340.

Tayler, C. (1979). Hegel and modern society. Cambridge: Cambridge University Press.

Thompson, C. (2006). Back to nature? resurrecting ecofeminism after poststructuralism and third-wave feminism. The University of Chicago Press Journals, 97(3), 507.

Walker, M. U. (1989). Moral understandings: alternative "Epistemology" for a feminist ethics. Hypatia, 4(2), 22.

Warren, K. (1990). The power and promise of ecological feminism. Environmental Ethics, 12(2), 141-143.

Wilson, H. L. (1997). Rethinking Kant from the perspective of ecofeminism. In R. M. Schott, Feminist interpretation of Immanuel Kant (p. 377). Penn State University. 
Zimmerman, M. (1987). Feminism, deep ecology and environmental ethics. Environmental Ethics, 9(1), 34. 